\title{
Using Quentin Skinner in history and philosophy of education
}

\section{Utilizando a Quentin Skinner en la historia y la filosofía de la educación}

\section{Utiliser Quentin Skinner en histoire et philosophie de l'éducation}

\author{
Carlos Martínez Valle \\ Universidad Complutense de Madrid, Spain
}

\begin{abstract}
Quentin Skinner's work is central to Intellectual History. This article reviews his methodological critiques and exegetical recommendations as they can be of interest for historians of education, educational comparatists, and analysts of educational policies. The article analyzes Skinner's proposals against alternative methodologies. Firstly, it explores the criticisms he makes to traditional forms of the History of Ideas. These criticisms attack, in an original way, well known fallacies that are also common in History of Education. Secondly, the article explores his constructive proposals based in linguistic philosophy. The article introduces Skinner's idea of "meaning," which focuses on the intention of the author in issuing or writing the utterance or text. This intention can be worked out by considering the linguistic-rhetoric context of the work. The focus on intentions and contexts, which puts at the center of the exegesis what was considered a fallacy among positivist historians, implies a change in the conception of History of Education and in its relation to Philosophy of Education. The article sketches, as a way of conclusion, some implications of these constructive proposals for the work of comparatists, historians and philosophers of education.
\end{abstract}

Key words: Quentin Skinner, methodology, history of ideas, intellectual history, meaning, intention, exegesis.

RESUMEN

La obra de Quentin Skinner fue un revulsivo contra la tradicional Historia de las Ideas y una de las bases de la Historia Intelectual. El artículo repasa, confrontándolas a otras alternativas, 
sus críticas y recomendaciones metodológicas pues pueden ser útiles para historiadores y comparatistas de la educación y analistas de las políticas educativas. Para ello, analiza sus críticas a la Historia de las Ideas, que atacan de una manera original falacias históricas también extendidas en la Historia de la Educación. El artículo prosigue presentando sus propuestas metodológicas positivas. Introduce su concepto de significado que traslada desde la filosofía del lenguaje de Wittgenstein y Austin y que asimila a la intención en la producción de la elocución o el texto estudiado. Esta intención se puede inferir considerando el marco retórico-discursivo de la elocución o texto, lo que pone en el centro de la interpretación la que había sido considerada una falacia por el textualismo positivista. Este nuevo acercamiento implica una transformación en la Historia del Pensamiento y, trasladado, de la Educación y de su relación con la Filosofía Política o, respectivamente, Educativa. Como conclusión, el artículo pergeña algunas implicaciones de estas propuestas para la Historia y Filosofía de la Educación.

Descriptores: Quentin Skinner, metodología, historia de las ideas, historia intelectual, significado, intencionalidad, exégesis.

\section{RÉSUMÉ}

L'œuvre de Quentin Skinner est centrale à l'Histoire intellectuelle. Cet article examine ses critiques méthodologiques et ses recommandations exégétiques parce qu'elles peuvent être d'intérêt pour les historiens de l'éducation, les comparatistes de l'éducation et les analystes des politiques éducatives. L'article analyse les suggestions de Skinner contre les méthodologies alternatives. Premièrement l'article explore les critiques qu'il fait sur les formes traditionnelles de l'Histoire des idées. Ces critiques attaquent de façon originale les idées fausses bien connues qui sont aussi communes dans l'Histoire de l'éducation. En second, l'article explore ses propositions constructives fondées sur la philosophie linguistique. IL introduit l'idée de Skinner au sujet du «sens», qui se centre sur l'intention que l'auteur avait en exprimant sa parole ou en écrivant le texte. Cette intention peut être déchiffrée en considérant le contexte linguistiquerhétorique de l'ouvrage. En se centrant sur les intentions et les contextes, il met au cour de l'exégèse ce qui était considéré comme une fausseté parmi les historiens positivistes, ce qui laisse entendre un changement dans la conception de l'Histoire de l'éducation et dans sa relation à la Philosophie de l'éducation. L'article ébauche par manière de conclusion certaines implications de ces propositions constructives pour le travail des comparatistes et des historiens et philosophes de l'éducation.

Mots clés: Quentin Skinner, méthodologie, histoire des idées, histoire intellectuelle, le sens, I'Intention, l'exégèse.

\section{Introduction}

"Cette manie qu'avait Swann de trouver ainsi des ressemblances dans la peinture était défendable, car (... est ...) quelque chose de général, et a pu se rencontrer à différentes époques. Mais si on avait écouté Swann, les cortèges des rois mages déjà si anachroniques quand Benozzo Gozzoli y introduisait les Médicis, l'eussent été davantage encore puisqu'ils eussent contenu les portraits d'une foule d'hommes contemporains non de Gozzoli, mais de Swann (...). Il n'y avait pas selon Swann, dans ces cortèges, un seul Parisien de marque qui manquât." (Marcel Proust, A l'ombre des jeunes filles en fleurs.) 
A $S$ WITH Proust's M. SwanN, who recognizes in Renaissance paintings his acquaintances of Paris' grand monde, a part of the literature on Political and Educational Philosophy and History has interpreted the great authors of the past as its own contemporaries. This literature has read the canon texts as part of timeless debates on eternal problems, which made the great authors worthy of being re-read always anew. Another part of the literature has construed lineages of ideas as foreseen answers to today's problems, as if they were organisms evolving in a necessary teleological progress. In this grand monde, the canonical authors connect and influence each other, even retroactively, as recent eminences can illuminate the work or even rediscover the true meaning of their predecessors, creating a chain of ideas that fuels progress. However, even the "high modernist" Proust seems to have taken an ironic distance towards this peculiarity of M. Swann (Schmidt, 2012).

Of course, History left the good society many years ago, for mixing with other disciplines and researching the lives of common people, societies, and institutions. However, the problem is still present: How much can we learn about today's troubles from past experiences and ideas? What are we doing with all the Classics of the "great pedagogical tradition," if oracles have become only dusty busts? What can we do with Ferriere, Freinet, or Freire, if we are not using them to illuminate the obscure future of us? The question remains: How to understand past authors and texts? How to understand Sáenz's Carapan?

Furthermore, is it meaningful to elaborate lineages or taxonomies of educational ideas and thinkers? Is it sensitive to consider Kerschensteiner's Arbeitsschule and the Montessori School or Steiner's Waldorfschule under the same concept of Reformpädagogik? What are these lineages good for? These questions are not merely rhetoric or unspoken appraisals of Nominalism.

Similar hermeneutical problems arise in studying educational policy, and the educational features of foreign societies and transfer. Did the curricular reforms of English History, Literature, and Culture made in Raj India have the same meaning as the same measures taken by the post-war Queen's government (Viswanathan, 1989)? Was Mexico's Secretary of Public Education, Vasconcelos, proposing a reactionary curriculum when he supported old classical curriculum against the socialist school?

Quentin Skinner's proposals ${ }^{1}$ deal with these problems, and could be translated into the History of Education. There have been radical changes in History since Skinner began to publish, due to, among other things, Social History and different historiological turns. Skinner's methodological recommendations have already been explicitly invoked by historians of education (for instance, Brehony, 1997; BrunoJofré \& Zaldivar, 2014; Howlett, \& Mac Donald, 2011; Tröhler, 2013). In this sense, this article aims at revisiting Skinner's work, again, as his methodological critiques and exegetical recommendations ${ }^{2}$ could still be of interest for educational historians and comparatists and analysts of educational policies. The moment seems propitious, as, amongst other recent works, the transfer studies conducted at Humboldt University have revitalized the interest in Intellectual History in Education (Bruno-Jofré \& Schriewer, 2009, 2011; Popkewitz, 2008; Schriewer \& Martínez Valle, 2003, 2004). This article analyzes Skinner's proposals against alternative methodologies. Firstly, 
it explores the criticisms Skinner makes to traditional forms of the History of Ideas. These criticisms attack in an original way well-known fallacies, and the article studies them in relation to History of Education. Secondly, it explores Skinner's constructive proposals as a non-naturalistic reaction to positivism based in linguistic philosophy. The article introduces Skinner's idea of "meaning," which focuses on the intention of the author in issuing the utterance or text. The author's intention can be worked out by considering the linguistic-rhetoric context of the work. The focus on intentions and contexts implies a change in the conception of History of Education and in its relation to Philosophy of Education. The article sketches, as a way of conclusion, some implications of these constructive proposals for the work of comparatists and historians and philosophers of education.

\section{Skinner's critiques}

“Ce qu’on appelle la postérité, c'est la postérité de l'œuvre. Il faut que l'œuvre crée elle-même sa postérité. Si donc l'œuvre était tenue en réserve, n'était connue que de la postérité, celle-ci, pour cette œuvre, ne serait pas la postérité mais une assemblée de contemporains ayant simplement vécu cinquante ans plus tard.” (Marcel Proust, A l'ombre des jeunes filles en fleurs)

If there is something characteristic of Skinner's work, it is the consideration of thinking and writing as the intentional act of taking a stance against other ideas. This agonistic conception shows up recursively in his own methodology - that is, his way of reasoning and stating his positions has clear parallelism with his methodological ideas, as he discusses and states his positions against opposed methodological stances.

Skinner rejected two established History of Political Philosophy schools. Leo Strauss and Arthur O. Lovejoy, despite their different approaches, continued the tradition of the hermeneutical study of canonical authoritative texts. Their approach, Skinner criticizes, aimed at discovering the perennial truths of political philosophy, which produced an "ontologization" of the texts as concretions of a teleological (even retrospective or prolapsian) discourse. As, in their narratives, ideas became hypostatized into a sort of immanent entities, the role of the History of Ideas was to trace the morphogenesis of those entities. The genealogies so construed, pace Skinner, obliterate the contingency of socio-political life as evolution and progress become necessary (Skinner, 2002, pp. 62 ff., 75, 83).

For rejecting this politically conservative and methodologically traditional History of Ideas, which deprived the works of its historical specificity, Skinner draws on the advances in the praxis of the History of Political Thought. An example of this was Peter Laslett's introduction to John Locke's Two Treatises of Government. Through accurate dating, Laslett uncovered the fact that Locke's works were neither a retrospective philosophical rationalization for justifying the English Revolutions, nor a defense of liberal principles against Hobbes, as commonly held. Locke's works were, as the subtitle plainly informed, an argument against "the false principles and foundations of 
Sir Robert Filmer," particularly the conception of property and government explored in Patriarcha, the intellectual basis for the de jure divino Stuarts' claims. The reappraisal of Locke's work changed its consideration from a work of political philosophy to a political instrument, exposed the fallacies (generalization, propter hoc, prolepsis) and blatant deficits of the old hermeneutic tradition (the oversight of the subtitle), and showed some of the opportunities of the new heuristics. Another model for relating History and Philosophy, studying agency in concrete historical situation, was provided by Collingwood, who insisted that every historical time has its own issues, problems, and answers, and the role of both History and Philosophy is "to reveal and explain each other these problems, questions and answers." Both taught Skinner the task of "seeing things their way," rejecting the ex post/retrospective imposition of modern conceptions (Skinner, 2002, pp. 1 ff., 83 ff., 87).

Following their examples, Skinner makes a devastating critique to the presuppositions and procedures that create different "mythologies" in the narratives of the traditional History of Ideas, which could dissolve common fallacies ${ }^{3}$ of the History of Education as well. The constitution of Education as a doctrine - that is, as a practice directed by principles and values, to model an essential timeless human being - fosters a normative conception that privileges the establishment of canons of pedagogical ideas, the "monumentalization" of authors, and the adoption of teleological perspectives and lineages as interpretative instruments. In this context, it is normal that historians build expectations about their study subjects, incurring fallacies: "Our expectations about what someone must be saying or doing will themselves determine that we understand the agent to be doing something which he would not (...) himself have accepted as an account of what he was doing" (Skinner, 2002, p. 59). Partisanship, justification, and propaganda - diverse forms of parochialism or embellishment - are easy in these conditions.

Skinner's works denounce fallacies of composition, and quote out of text interpretations that confer to the studied works a systemic and coherent character that not even their authors desired (the myth of coherence). Contradictions, ambivalences, and silences are often veiled by Histories of Political Thought and Education. An obvious example could be the literature on Rousseau, which is prone to obliterate or to even the contradictions of his works and life. How many works analyze the ambivalences of, for instance, Dewey?

Skinner spurns the term "mythology of the doctrines," the narrative resulting from selective interpretation of texts, for fitting them into or construing predefined intellectual lineages, traditions, or schools. In this mythology, historians canonize and demote authors and texts depending on their contribution to the development of doctrines as evolving entities (fallacy of reification). In these mythologies, "agents readily disappear as the ideas get up to do battle on their own behalf" (Skinner, 2002, p. 62). Both mythologies of coherence and doctrines form the "paradigm priority," which introduces false continuities, structures, and order in History of Ideas. The questions here are: Can we consider Padre Manjón as part of the Reformpädagogike? (Röhrs \& Lehman, 1994). Is it true that Rousseau was a member of les Lumières? What was gained, for the understanding of his work, by including him in the Enlightenment's 
Parnassus? If "Puritan" has been used for defining both Milton and his archenemy Prynne, who hold opposed ideas and objectives, does it make sense to use this category in analyzing Milton's Of Education?

Skinner continues dealing with teleological fallacies of anachronism-presentism, historian's fallacy and of confirmation bias. He applies the term "mythology of parochialism" to the narratives derived from the use of the historian's ideas, criteria, and values in interpreting past works, using for instance "the concept in an apparently explanatory way without considering whether the conditions (...) for the application of the concept have been met." The result is that alien aspects of the texts "dissolve in a misleading familiarity" (Skinner, 2002, p. 75). The conflation or imposition of retrospective foreign meanings and objectives to agents, writers, or texts constitute what Skinner calls "mythology of prolepsis." Skinner asserts the alien condition of the classic texts as they "are concerned with their own problems, and not necessarily with ours" (Skinner, 2002, p. 73 ff.; 88).

The denouncement of the doctrine and parochialism mythologies is related to the questioning (against Strauss) of the factual influence between authors, and the pondering of Einfluss (influence) as intellectual instrument for writing History. Skinner determines the conditions for the existence of an intellectual influence from an author A to an author B: that author B has studied the works of author A and only there, and not out of personal reflection, could author B have learned the doctrines under scrutiny (Skinner, 2002, pp. 75-76). He maintains that after passing this filter, not much real influence remains in the History of Political Thought. His own intellectual practice could help to explain his position, although he doesn't seem to be prone to self-reflection. Skinner doesn't reject influence; his own loans from Wittgenstein, Austin, or Geertz are manifest. However, his loans could be understood from his premises in an instrumental and not morphogenetic way, as instruments used in other contexts for other purposes, not as part of the idea's evolution to a superior stage. But he doesn't criticize just the historical accuracy of the attributions of influence. Although he doesn't deny altogether its explanatory force, he states that "there is scarcely ever any point in doing so," as influence isn't much else than the capacity of the reader to "foreshorten the past by filling it with his own reminiscences" - that is, an $e x$ post facto fallacy (Skinner, 1969, p. 27). Surely, influence is mostly interesting from the idea of a continuum in a teleologically necessary accumulation of knowledge. Can we still consider Luther and Calvin the fathers of modern education, even if Calvin, for instance, put bluntly: "I'amerois mieux que toutes les sciences humaines fussent extermines de la terre, que si elles estoyent cause de refroidir ainsi le zele des Chretiens et les destourner de Dieu" (I rather eliminate all human sciences, to let them cool down the Christians' zeal taking them out of God's path) (Calvin, 1964, p. 600).

History of Ideas wasn't the only target of Skinner's critiques. The post-war consensus around the Welfare State, with its corollary of blurring cleavages, expert based policies, and management, produced a "scientization" of the humanities. Functionalism, System Theory, Behaviorism, and educational measurement became mainstream. In Skinner's field, many academics envisioned the end of political philosophy and its substitution through policy, and of individuals through social structures and laws 
(Palonen, 2003, p. 12).

This positivism found a counterpart in History, the radical methodological stance maintained by empiricists as Geoffrey Elton, who considered the métier of the historian to uncover and describe past facts in rigorous, systematic, and objective descriptions. Skinner uses Foucault for criticizing historical positivism-empiricism through a reductio ad absurdum of hard facts, inductivism, and of the idea of evidence as springing out of the facts. Foucault reminds readers that "all classificatory schemes are subject to endless challenge and revision" (Skinner, 2002, p. 8, 19). The most simple and apparently immediate (linguistic) definition of the facts, maintains Foucault, implies at least a rudimentary classification that determines its understanding/interpretation. As the concepts and frames used for categorizing the same facts differ in different spatial, temporary, and cultural spheres, the linguistic codification of these simplest facts produce divergent understandings of them. Furthermore, Skinner defends the necessity of presuppositions and a measure of interpretation that filters the sheer amount of facts for determining those relevant in a meaningful construct (p. 19).

These forms of positivism met old forms of the History of Political Philosophy, which considered political thought a mere "epiphenomenon" of economic or political struggle. Marxism and Lewis Namier considered political ideas instruments for obtaining power and justifying economic decisions or super-structural ideology, eradicating contingency, flattening History, and making exegesis unnecessary (Skinner, 2002 , p. 24, 145). Skinner accepts the fact that politics is about power and interests; however, he insists on the necessity of considering the constraints and chances of the discourses. From here, we may ask: Is the renovation of the Catholic schools in early 20th century Spain only a rhetorical move for attracting the growing middle class? Did the adoption of a new rhetoric change their understanding of education? (Kössler, 2009).

\section{Constructive proposals: Transforming philosophy of language into exegetic recommendations}

"The issue is epistemological. If we are going to cling to the injunction to see things from the native's point of view, where are we when we can no longer claim some unique form of psychological closeness, a sort of transcultural identification, with our subjects? What happens to verstehen (sic) when einfublen (sic) disappears?” (Clifford Geertz, Local Knowledge)

Skinner (2002) divides the non-positivistic currents of his time into three major traditions: phenomenology, Dilthey's hermeneutic, and the philosophy of language of Wittgenstein (p. 128 ff.) (Sometimes, he considers Weber a fourth one). In the History of Political Philosophy, Phenomenology and Dilthey's Geisteswissenschaften were already "occupied" by Leo Strauss and Lovejoy. Verstehen, for instance, was necessary for determining the real message behind the esoteric formulation of the classical texts in Leo Strauss' work, while phenomenology was the one of the instruments for determining Lovejoy's "unit-ideas." 
Wittgenstein's ideas were a good instrument for Skinner and a group of Scholars from Cambridge University who were also interested in Weber, Foucault, or Bourdieu, for creating a new "Historical Contextualism" or "Intellectual History" opposed to the above mentioned currents. These commonalities led to the coinage of the term "Cambridge School," although it has never been fully endorsed by their purported members and there were substantial differences in their proposals. ${ }^{4}$ Quentin Skinner has become one of the most quoted methodologists of the so-called Cambridge School.

Skinner writes encomiastically about the Begriffsgeschichte, equating some of his recommendations and practices with those of his Germans colleagues (Skinner, 2002, pp. 177-181). However, they have contradictory origins, premises, approaches, and objectives. To provide a cursory summary of them: 1) The Begriffsgeschichte arises from German hermeneutics, in particular Gadamer, ${ }^{5}$ Max Weber, and Nazi and reactionary currents, as the Volksgeschichte of Conze and Brunner (later Social History) and Karl Schmidt (Koselleck \& Dipper, 1998), while Skinner bases his ideas essentially on the "second" Wittgenstein. 2) Koselleck has stressed the autonomy of the Begriffsgeschichte as a discipline with its own methodology and content as the counterpart to Social History in a comprehensive History. Furthermore, he considers that it has a function as a method and instrument of Quellenkritik and auxiliary source for Social History (Koselleck, 1972b). Skinner's recommendations don't relate its proposals to other historical fields or comprehensive forms of History. 3) The main work of the German school, the Geschichtliche Grundbegriffe, attempts to reconstruct the morphogenesis of the contemporary concepts, and considers a period of rapid linguistic change or modernization called Sattelzeit (literally, saddle-time, watershed), that they situate, conventionally, between the Enlightenment and the first industrial revolution (1750-1870). ${ }^{6}$ These concepts are considered indicators and factors of social transformations, which presuppose ample levels of conceptual homogeneity and conventional acceptation. Skinner doesn't focus on the transformation of the concepts and Weltanschaunng in interrelation to social processes, but on their particular short-term rhetorical uses for concrete political objectives in concrete situations, denying fixed normative meanings. Therefore, for Skinner, the only possible History of concepts would be the History of the debates in which these concepts were used. So, it seems rather inappropriate to include Skinner within the general label of Conceptual History, although Hampsher-Monk (1998), among others, uses the term as a general frame for discussing his ideas. ${ }^{7}$

Skinner's methodological recommendations are, as the numerous quotations show, much closer to Clifford Geertz, ${ }^{8}$ who also reacted to British functionalism and Marxism. Both are linked to a rediscovering of the otherness, and committed to "seeing things their way" (Skinner, 2002, pp. 1-7), privileging thick cultural context over ahistorical universalisms. Geertz's work on foreign cultures made it easier for American cultural anthropology to discover diversity within Western countries. Intellectual History discovered other cleavages and ways of thinking that opposed or didn't converge in the modern ideas of individual freedom and the state or its Marxist cognates, as Republicanism or Divine Right Monarchy. For both, the task was to find 
a way to understand these old and alien debates and cultures, Verstehen obne Einfüblen.?

A main problem for historians and cultural anthropologists related to the issue of Verstehen (understanding) without Einfüblen (empathy) is how to approach and deal with those beliefs that the historian/anthropologist considers false and incomprehensible. Linking the issue to translation, and therefore to cultural anthropology, Skinner maintains that historians should ask about their and the text's contemporaries consideration of the rationality of the beliefs. Skinner ponders what can be considered, in a determined context, the criteria of rational acceptability: "for someone to hold a rational belief is merely for the belief itself to be a suitable one to hold true in the circumstances in which the agents find themselves." Then, the researcher should ask if the author maintains, for his or her context and the researcher's, false "belief in the light of, or rather in the face of, the criteria locally accepted as appropriate for the formation and testing of beliefs," focusing "not on the individual action (utterance) to be explained, but rather on the conventions surrounding the performances of such actions in the relevant social context" (Skinner, 2002, p. 141). This questioning is necessary, as the risks and the kind of explanations needed for those held true, then and now, are very different from those considered false by contemporaries or researchers. Beliefs that were considered skeptically in their context should be researched carefully, as they could be the expression of political motives. For those beliefs considered true by the historian, the researcher runs the risk of becoming confident and incurring fallacies of anachronism, losing meaning. Explaining beliefs considered false by historians forces them to sharpen their analytical instruments, going deeper in understanding the context and working out more consistent and comprehensive explanations (Skinner, 2002, p. 30, ff.).

The main inspiration for Skinner and Geertz was Wittgenstein's Philosophische Untersuchungen, which, by the time Skinner was a Cambridge student (1959-1962), was being applied to linguistics by Austin and became widely read. Skinner transformed their philosophic and linguistic reflections into heuristic recommendations. Three closely related ideas from these reflections became central in Skinner's thought: the conception of language as a social instrument, the idea of "meaning as use," and the Sprachspiele or linguistic games - that is, the plays made by changing the uses of the same terms in different concrete situations according to different objectives (Skinner, 2002, p. 104).

For Skinner, language as a social instrument is more than only a communicative instrument related to facts, but an instrument for, in Austin's words, "doing things." Skinner and Geertz share Austin's insight that utterances are actions: through talking or writing, people warn, promise, order, reject, and so on. ${ }^{10}$ This performative character of utterances was fixed by Austin in the concept 'speech act.' Therefore, for both, recovering the meaning of an utterance implies necessarily not only understanding the semantic content of the (terms of the) utterance, but crucially, what the actor was doing in issuing these utterances, for a determined audience, and in a particular occasion and debate.

Skinner considers language a social instrument, so that its contents should be, in Skinner's quotation of Geertz, "intersubjectively understandable," as "the intentions 
underlying such performances must be entities with an essentially public character." "As Clifford Geertz has finely remarked," wrote Skinner, "ideas are 'envehicled meanings'; they are not, and have not been for some time, unobservable mental stuff" (Skinner, 2002, p. 97). ${ }^{11}$ Political philosophy or culture aren't esoteric languages (as for Leo Strauss), or transcendental forms, meanings, or structures (as for Lévi-Strauss or Lovejoy), or philosophical conversations with the future, but rather alternative instruments for doing things (Palonen, 2003, p. 17). ${ }^{12}$ "Culture is public, because meaning is" (Geertz, 1973, p. 12).

As the meanings of words are determined by their use in language, and as words are instruments for doing things, a proper understanding of their meaning necessarily involves determining the intentions of the agents that use them. As agents use the same words for doing different things in different occasions, and with different meanings, it isn't possible to determine fixed normative meanings but rather context and objective-related uses of language. This is what Wittgenstein called the Sprachspiele, the linguistic plays done with words that are tools.

\section{Meaning}

"Mme. Swann, au moment où sa fille allait partir la rappela avec une extrême vivacité: “Gilberte!” et me désigna (...). C'est en vain que je disais: 'il me semble que l'autre jour la pendule retardait plutôt', elle traduisait évidement: 'Comme vous êtes méchante!'”

(Marcel Proust, A l'ombre des jeunes filles en fleurs.)

Skinner backs up these ideas in Austin's analysis of the different layers of meaning of socially significant utterances: what the agents say (the locutionary act), what agents mean in saying something (illocutionary act), and what the agents mean by saying something (perlocutionary act). Skinner explains these concepts by using the image of a police officer shouting to a skater that the ice of the pond where he is skating is very thin. The locutionary element is contained in the five words "the ice is very thin," However, the analysis of those words doesn't exhaust the meaning of the sentence. On the contrary, a reductive decontextualized analysis could lead to consider the words a mere factual statement. In fact, what the policeman does in saying these five words is not a mere ascertainment of the thickness of the ice. He is not asking the ice skater to validate the correctness of the utterance, but asking the skater to leave the pond. The speech act has, then, another meaning, the illocutionary act - in this case, a warning or an order to leave the pond. Furthermore, as a result of the locutionary and illocutionary acts, the skater may get off the pond, the perlocutionary act (Skinner, 2002, p. 104 ff.). Geertz (actually, Gilbert Ryle) develops on the nucleus of his methodological recommendations, the thick description, a similar argument around the differences between a nervous blinking and a conspiratorial winking (Geertz, 1973). The same differentiation serves not only for utterances, but for cultural acts: "Acts are in turn texts: they embody intersubjective meaning that we can hope to read off" (Skinner, 2002, pp. 120). 
As the example shows, retrieving only the conventional locutionary meaning of the utterance's words is necessarily too reductive: the same concept could be understood even in contradictory ways as a part of a Sprachspiel. A study of the uses of language in the History of Political Thought should focus on the intentional or illocutionary force of language as the real meaning beyond the semantic constitution of the utterance. Therefore, "to issue any serious (sic) utterance is always to speak not only with a certain meaning but also with what Austin dubbed a certain illocutionary force" (Skinner, 2002, p. 120, 98). Thus, Skinner equates what the actors mean doing the speech act with their intentions in doing it, and the decoding of the meaning of a linguistic action with "understanding the nature of the illocutionary act performed by the speaker" (Skinner, 2002, p. 133). From the perspective of the speech acts, utterances are not propositions or references to facts, as positivistic philosophies of language maintain, but arguments or instruments. So considered, concepts can't convey full meanings, as meanings don't refer to facts but to intentions. Concepts can have locutionary meanings but, as such, no illocutionary meaning.

These linguistic distinctions can be directly translated to the historic exegetic work with texts, as texts are, for these followers of Wittgenstein, utterances. Texts should be interpreted considering primarily the illocutionary act and not the semantic meaning: "The understanding of texts presupposes the grasp of what they were intended to mean and how that meaning was intended to be taken." As for other utterances, "to understand a text must at least be to understand both the intention to be understood and the intention that this intention be understood, which the text as an intended act of communication must have embodied" (Skinner, 2002, p. 87). This approach is contrary to the proposals of "textualism," an exegetic method castigated by Skinner, which focuses on the semantic, and, like positivism, considers it a fallacy to interpret the text through the intentions of the writer.

Skinner bolsters these ideas, pointing at the limits of the traditional semanticcentered exegetic methods, and clarifies his position against those who consider that searching for the intentions of the authors is methodologically untoward, as involving a sort of introspective empathy. For Skinner, the failure of textualism shows up in its difficulty to deal with two basic instruments of political rhetoric: irony and hidden meanings. Let's consider, using the same example, that the police officer shouted in an ironic tone that the skater should skate to the middle of the pond until the ice breaks... (Imagine Paul Goodman asking for a compulsory schooling for people of all ages). In ironic utterances, the illocutionary meaning is often contrary to the locutionary meaning. The semantic redescription of the utterance/text proposed by textualism could be misleading, as irony is not fully understandable without knowing the intentions of the author in issuing the utterance and analysis of the context.

Skinner contends that personal unspoken motives and intentions, which could be forces or antecedent conditions in the production of any utterance, can't be taken into account for the understanding of the utterance/text. Skinner rejects this kind of Verstehen of the inner thoughts, which he associates with Collingwood, calling it a "conjuring trick" (Skinner, 2002, p. 120). However, as the texts and social acts are not part of private states of conscience but public intersubjective communication means, 
empathy isn't necessary to recover the ideas from the foro interno of the agent. As in the communication between the police officer and the skater, the intention of every utterance (text), even if it isn't conveyed explicitly in the words said, should be manifest. The other way around: for Skinner, intentions are not mental acts but a substantial part of communication and, as such, fully understandable socially. Meanings, as "public and intersubjective" intentions, can be inferred from text and context.

Skinner doesn't reduce the whole work of the historian to the search for the illocutionary act. He accepts that texts have a life on their own and unintended surplus meanings for the readers. He accepts also, after different criticisms, that not all authors know how to convey their intentions, that texts aren't necessarily transparent for their own authors (Keane, 1988), and that not all authors are clear about their intentions. His point is that what the author was doing in writing must be a central piece in interpreting the text (Skinner, 2002, p. 101).

\section{Context and rhetoric}

Considering political texts as illocutionary acts implies, in particular, the focus on the context and on rhetoric: "the chief aspiration underlying the method I have been describing is that of enabling us to recover the historical identity of individual texts in the history of thought. The aim to see such texts as a contributions to particular discourses (... recognizing) the way in which they followed, or challenged or subverted the conventional terms of those discourses themselves (Skinner, 2002, pp. 124-5).

The problem is, then, how to determine the illocutionary act of a given utterance or text. Pointing to the use of context for explaining historical agency was a truism widely accepted in History, even at the moment of the publication of Skinner's reflection. Skinner proposes not a socio-economic but a linguistic-rhetoric-discursive context. He summarizes the procedure as follows:

if the question we accordingly need to confront in studying such text is what their authors could in practice have intended to communicate by issuing the given utterances $(. .$.$) the most illuminating way of proceeding must be (...) to delineate the$ full range of communications that could have been conventionally performed on the given occasion by the issuing of the given utterance. (...) the next step must be to trace the relations between the given utterances and this wider linguistic context as a means of decoding the intentions of the writer. (Skinner, 2002, pp. 86-87)

The historians, then, have to research, on one side, the "social imaginary, the symbols and representations of the age's subjectivity" (Skinner, 2002, p. 102), and the linguistic conventions that frame the illocutionary act and that make it understandable and allow its rhetorical transformation. On the other side, they have to "grasp the nature and range of things that could have been done by using them at this point" by considering the debates in which the work could have done something - that is, could have made a "move." In this sense, the context isn't a determinant of the speech act, but rather the framework of its conditions of possibility. Therefore, context should 
act as "a sort of court of appeal for assessing the relative plausibility of incompatible ascription of intentionality" (Skinner, 2002, p. 87). Actually, its role is negative: in framing the semantic-rhetoric conditions of the utterance, the context helps to restrain anachronism.

This role of context implies what, taking Geertz's words, could be called "thick description" of the cultural and political discursive context. In the praxis, this means the study of the myriad of minor forgotten works that framed the discussion and permit finding out the objective of the utterance and the election of the rhetorical means.

Another, related, problem of his proposal is that if the intention of the text has to be found through other texts and speech acts that are necessarily intertwined and need also to be interpreted, the differences between both blurs, and interpretation can enter a recursive loop. It would make necessary the application of the interpretive instruments, and therefore the historian's frames for deciding. Contextualism, Skinner's solution, can become a kind of extended textualism, one of his original targets of criticism (Clarke, 2013). Skinner is aware of the hermeneutic difficulties and uncertainties in the determination of the illocutionary act and the meaning of the text. He accepts that, in the best case, the choice will remain an inference, but he contends that this is a general problem that affects all social and hermeneutical research procedures (Skinner, 2002, p. 121).

The understanding of the linguistic-intellectual-discursive context requires the knowledge of rhetoric. Agency, through utterances or texts, has to consider the conventional meanings and forms to be understood, but also the mechanisms to change and subvert these conventions for conveying intentions and modifying the discursive context. For Skinner, language and rhetoric are, at the same time, a "structural constrain" and a "resource for agency" (cited in Palonen, 2003, p. 7). Skinner explains the relation between these two poles through the example of the agents analyzed by Max Weber in The Protestant Ethic and the Spirit of Capitalism. The north European merchants made, pace Skinner, a transforming political move when they adopted and manipulated a Christian language for legitimating, sanctioning, or in this case sanctifying activities that were considered untoward by the previous holders of this language. Politics and political thought, as well as rhetorical and moral conventions, are established, maintained, or debunked by these "innovating ideologists" who introduce change through rhetoric manipulation (Skinner, 2002, pp. 148-149, 182).

However, his understanding of rhetoric shows the restricted specificity of his focus, which forgets processes and formal aspects. Skinner pays attention to the inventio and dispositio but forgets about the elocutio, which is central to rhetoric. It is understandable, as he isn't interested in the social processes around the ideas: convincing, diffusing and adopting, mobilizing, and other forms of political agency, but mainly in speech acts through texts (Jay, 2013).

As rhetoric frames speech acts, similar moves with similar intentions would take place, adopting similar rhetorical moves. Therefore, rhetoric somehow takes the place that traditional literature concedes to influence as a way for ordering the myriad of expressions of political debate, creating what Palonen has called a "rhetorical 
perspective" (Palonen, 2003, p. 12).

The consideration of rhetoric poses the question about the existence of languages and the differences between the conventional and normative value of concepts and, again, the historiological difference from the Begriffsgeschichte. Skinner maintains that the rhetorical use of terms (to make a move in arguments) could impose, on the same terms, opposed locutionary and illocutionary meanings. As concepts have no independent apparition (life) from their uses in utterances, and ideas are used as rhetorical instruments for strategic purposes, terms take their meanings from the general meaning of the utterances, therefore it isn't possible to make a History of concepts, as "the only Histories of ideas to be written are histories of their uses in argument" (Skinner, 2002, p. 86, 176). Therefore, from Skinner's perspective, the Begriffsgeschichte could, very much in the manner of Lovejoy's unit-ideas, ontologize and essentialize their concepts.

Although his methodological work is finely perceptive of the fallacies paving his time's History of thought, Skinner's recommendations incurs methodological problems as result of its stringency. Translating directly from Linguistic Philosophy to History, he equates, in a non sequitur, texts with speech acts, forgetting that the conditions and possibilities of communication for the spoken and the written acts are different. As shown by the Histoire Culturelle, which was more interested in and was more perspicuous about cultural processes, written acts are not time and space-bounded. The context of the debates can be, in textual communication, of a longue durée. The second presupposition is the consideration of direct immediate political problems as the only source of intention and context of the illocutionary act, and therefore of the studied works. These two presuppositions coalesce in a petitio principii: all political works discuss short-termed political fights (Lamb, 2009). Intellectual History should, therefore, only focus on short-termed instrumental uses of ideas.

Highly normative, doctrinal fields as Politics and Education tend to base or convey their prescriptive contents in at least some metaphysical, physical, or anthropological conceptions. Political works can discuss these prescriptions, which surely have a political and circumstantial character, but also the foundations, which could have a longue durée. Furthermore, authors don't write in an institutional vacuum and could have had programmatic, systematic, or philosophical objectives. For instance, this is evident in those related to universities or other institutions that aim at justifying political systems or educational models. At any rate, the circumstantial character of political utterances can't be stated a priori, but must be proven for every case. Furthermore, the practical difficulty of such stringently diachronic history is shown in Skinner's own historical works, which were devoted in a conventional and contradictory manner to a quite synchronic study of those currents that set The Foundations of Modern Political Thought, or even to A Genealogy of the Modern State (Skinner, 1978 and 2009, my emphasis). ${ }^{13}$ History is, for many of its practitioners, not only a place but a journey.

Although explicitly anti-idealistic, the stringent conception of influence, the obliteration of historical processes of different duration, and of broader socio-institutional conditions of knowledge production have constituted a hurdle for reaching beyond 
the small realm of the political (philosophy and economy) and the culture savant. It has impeded a cross-disciplinary work, the opening to other fields, and therefore has restricted its Anschussfähigkeit (literally, connectivity; also, usability). Nothing of the surprising links between different intellectual and artistic fields (Hunt, 2010; Perrot, 1992; Revel, 2008) studied by Cultural History has come out of Skinner's proposals. He didn't pay attention to the processes, practices, and instruments of creation, diffusion, and adoption of knowledge (reading, writing, sociability, the book, and so on) that are central for Education as, for example, Chartier or Certeau have done. Skinner's work neither considered the relevance of general anthropological issues such as feelings, attitudes, beliefs, symbols, common sense, or cultural practices that are connected with education and were studied by the more traditional History of Ideas (McMahon, 2014). Its focus and potentiality remain confined to the analysis of the meaning of (political) texts in contexts. This is also its main use in Education.

\section{As a way of conclusion: Skinner's constructive proposals and history and philosophy of education}

Skinner transformed a linguistic philosophy into exegetical-methodological recommendations for History and, in doing so, he questioned the contents and objectives of the History of Political Thought, and therefore its relation with Political Philosophy. His recommendations seem to spring out of the same matter of politics, as they imply authors confronting themselves and using ideas rhetorically for pursuing their objectives and interests. This article has already analyzed the relevance for History of his critiques. His constructive proposals can also contribute, conveniently translated, to History and Philosophy of Education. From the more specific to the most general contributions, we could mention valuable interpretative instruments, the opening of new research areas, the questioning of influence, the transformation of the conception of the relationship between History and Philosophy of Education and the uses of History as a critical instrument for a radical questioning of engrained cultural and disciplinary assumptions.

Skinner's proposal of the illocutionary act as a central piece in the interpretation of texts (and acts) could constitute a sharp critical instrument against false genealogies, teleological assumptions, anachronisms, and immoderate interpretation, introducing differentiation and precision. A good example could be Anne Marie Chartier's (2007) analysis of the intentions of La Salle in introducing his letter-syllabic reading method. The literature had interpreted this method as the product of the application of the Cartesian principles of analytic segmentation to reading methods. Against this speculation, Chartier maintains, convincingly, that the new method was a device designed by La Salle for artificially stretching out the reading and schooling times in order to increase religious education. It isn't important if Chartier has drawn on Skinner in this analysis, but rather that this instrument finds a methodological formulation in Skinner's work. Skinner's proposals can change well-established readings of other authors. In the same vein, and explicitly referring to Skinner, Bruno-Jofré and Igelmo (2014) interpreted Deschooling Society as an attack on the magisterial power of the Catholic Church: Illich was at odds with the Catholic Church because of the 
neocolonial character of the missionary programs designed by the Vatican and the USA.

Skinner's rejection of influence has also been used in comparative education and transfer studies. It was borrowed, although not explicitly, by a series of works on the globalization of the educational discourses and the transfer of educational ideas. The analysis of the intellectual borrowings in the educational discourses of China, Russia/Soviet Union, and Spain throughout the 20th century - and, in particular, the transfer-reception processes of particular authors in those spaces (Schriewer \& Martínez Valle, 2003, 2004) - have shown that the long established idea of the global influence of the great thinkers, and also policy designers, should be taken cum grano salis. The quotations from the classics of the progressive education, such as Dewey, rather than a comprehensive and understanding translation and adoption process, were often only name-dropping, or a selective and transforming reading in which very schematic ideas belonging to general discourses were distorted in order to adapt them to the specific cultural frames and political debates of the receivers. At least in those three discourses, rather than ideas, authors were quoted as prestige labels and political instruments. One classic example could be the influence of Dewey in post-revolutionary Mexican education: the Mexican government highly praised the inspiration, and Dewey thanked the government for putting into practice his ideas. However, the praise was more the recognition of similar political alignments, as the ideas received under his name were either generalities or different from the original. There are no documented readings of Dewey until Rafael Ramirez retired and had time for reading, as Moises Sáenz - Mexico's Vice Minister of Education and Dewey's presumed student and paladin - never studied with him and held radically different educational ideas (Bruno-Jofré \& Martínez Valle, 2012).

The analysis of the intentions of the authors in History of Education could foster the study of the educational rhetoric and of the interrelation between linguistic and ideological changes, as it did in History of Political Thought (Skinner, 2002, p. 87 ff.). Furthermore, the need to study the context would open the research focus for including the mass of forgotten or misread educational works and debates. It could open the focus from Comenius, not only (for instance) to Hartlib and Dury, but also to the myriad of educational writings of other denominations. Skinner's recommendations incite historians to deal with a wealth of debates and works displaced in the construction of the educational canons, a research that can be particularly fructiferous for time periods prior to the institutionalization of the educational systems. It could allow for including neglected cleavages and debates, such as the ArminiansGomaristen. It could also serve for taking politics into account seriously.

Another main gain is a radical attack on a traditional, although progressively less frequent, conception of History of Education and its relation with Pedagogy and Educational Philosophy. The doctrinal-normative constitution of Pedagogy (and Education) means that their Histories became a repository of inspiration and knowledge, for a praxis conceived often in essentialized, abstract, and timeless terms. These teleological narratives and answers implicitly turned History of Education into an auxiliary discipline of Pedagogy. ${ }^{14}$ A similar constellation happened in Sociology, 
as Jones (1981) analyzes. Skinner's critique to this relation is radical. If "any statement is inescapably the embodiment of a particular intention on a particular occasion, addressed to the solution of a particular problem (...) The implication is not merely that the classic texts are concerned with their own questions (...) it is also (...) that there are no perennial problems in philosophy" (Skinner, 2002, p. 88).

This move could be understood as a "ground clearing for the normative political philosophy to flourish afresh," (Lane, 2012) parallel to those proposed in Rawls' articles of the 1960s for creating a new political philosophy from a blank slate (Tuck, 1993). The radical negation of the existence of perennial questions and answers in Education could be also refreshing for Pedagogy and Philosophy of Education, as it would place the philosopher or theoretician of education in the need of reconsidering the contingency of historical evolution, and therefore of the ideas that should mold it.

However, his way of understanding History and the texts, fixing them to the small local and short temporal frames of their contingent minute and dully original debates, has been contested as a narrative only interesting for antiquarians. The focus on the study of fully alien debates could reduce, as Skinner writes, "the study of the history of thought to nothing more edifying than a conducted tour of a graveyard" (Skinner, 2002, p. 125). In fact, this kind of History could put his historian in a similar situation to the one Skinner envisions in the positivist currents, facing a meaningless babbling.

Skinner rebuts this image, explaining what could be the interest of such an Intellectual History. He affirms that the gains of his procedure take place in higher abstraction levels. The "strict diachronic approach," and the detachment it produces, allows for a new "dialogue between philosophical analysis and historical evidence" in which the later term counts. In fact, Palonen considers this move a revolution in the History of Political Thought, as it places political life and not Political Philosophy at the center of the research, making the latter a reflection of the praxis. This takes the discipline out of the hands of the chosen few that understand the esoteric philosophical jargon, and produces a democratic recovering of politics as generally understandable, everyday activity that deserves to be studied by History.

Translated to History and Theory of Education, the "diachronic approach" can help to question the normative content of theory of education for putting the focus on the problems and development of the educational praxis, and therefore on the mutual influence of praxis and reflection. Furthermore, in such a normative discipline as Theory of Education, the adoption of Skinner's recommendation could help to dissolve the pretensions of educational equanimity of the reflection about ideal models for displaying its factional political cleavages. It would allow for a History of the Theory of Education that would show not the false agreements produced by sharing a similar lexicon but its fractures and positions, which could be a stimulus for opening new paths, open to all interested. In this sense, this history of the theory would bring it closer to a more critical Philosophy of Education.

This contextualizing approach parallels, somehow, new methodological reflections on Comparative Education that maintain that the objective of the discipline is 
neither to recover the big picture of the structural similarities nor the determinants of specific societal characteristics as proposed by Mill, but to describe accurately the distinctive characteristics of every case of study (Schriewer, 1999).

However, the main gain of Skinner's approach, of "seeing ourselves (...) as one tribe among others" (Skinner, 2002, p. 125) is an estrangement effect by which we take distance from our own assumptions. "The investigation of alien systems of belief provides us with an irreplaceable means of standing back from our own prevailing assumptions and structures of thought, and of situating ourselves in relation to other and very different forms of life (...) such investigations enable us to question the appropriateness of any strong distinction between matters of 'merely historical' and 'genuinely philosophical' interest, since they enable us to recognize that our own descriptions and conceptualizations are in no way uniquely privileged" (Skinner, 202, p. 125). Reckoning the provincialism of our beliefs and arrangements should foster objectivity, comprehension, tolerance, and self-critique against parochialism and openmindedness towards alternative options (Skinner, 2002, p. 89). These are abilities that could help us in the transition to a world in which the school is no longer the main social instrument for socializing new citizens.

\section{Notes}

1. For simplicity's sake, when possible I quote from Visions of Politics, a recent volume that compiles most of Skinner's methodological reflections and proposals.

2. The precise epistemological status of Skinner's proposals (method, hermeneutic or exegetical considerations, methodological recommendations) isn't clear, and has been questioned by his critics. He hasn't cleared the problem himself, although some of his utterances, in particular the adverbs, seem to endorse the self-understanding of his proposals as a method. I have chosen, in my opinion, the most neutral term methodological recommendations - as Skinner himself uses it when speaking about the application of philosophy to the research practice (Skinner, 2012, p. 140). Jones (1981) also uses it.

3. One example: the traditional role of vicarious learning in the study of Pedagogy and Teacher Training, and the proposition of educators of the past as models for the future teachers. The "monumentalization" habit is exemplified for Decroly in Pozo Andrés (2007). This is a recurrent phenomenon, as shown by the adscription of the Project Method to Dewey or the praising of a (non-existent) influence of Dewey on numerous educational reforms across the globe, as in post-revolutionary Mexico or republican Spain (Bruno-Jofré \& Martínez Valle, 2012).

4. However, the work of the group has been studied through the sort of apparatus that accompany a paradigm - for instance, Burke (1997); Hampsher-Monk (1998); Tuck (1993), and Tully (1988).

5. Gadamer (1993, p. 9) considered that many modern German "key concepts and words which we still use acquired their stamp" in Goethe's century. 
6. Some entries of the Geschichtliche Grundbegriffe don't make a clear connection between general social processes and the semantic changes, and instead of collecting socially widespread uses of their termini, resort to canonical works to show the conceptual evolution. Other entries, as "Freiheit," contradict some central hypothesis of the theory, as it affirms explicitly that the conceptual changes took place before the Sattelzeit (Bleicken, 1972). See also Olsen (2012, p. 199, n. 47).

7. The best overview of the Begriffsgeschichte is Koselleck (1972a); for explanations of the BG and comparisons, see: Hampsher-Monk (1998), Olsen (2012), Palonen (2004), and Richter (1990, 1995).

8 . For the leading role of cultural anthropology in different turns, see BachmanMedick (2007) or Lepenies (1981, pp. 179-197).

9. Although Einfühlung is usually associated with Dilthey, he neglected the idea in later works.

10. "Wittgenstein has instructed us to think about the use of language, and it appeared to me that Austin picked up this suggestion and run with it. The outcome was a wonderfully precise anatomy of what might be meant by talking about the enormous range of uses" of language. (Skinner, Koikkalainen, \& Syrjämäki, 2002, p. 47).

11. Here, Skinner refers to Geertz, C. (1980). Negara: The theatre state in 19th century Bali. Princeton, NJ: Princeton University Press, p. 135.

12. "His (Wittgenstein's) attack upon the idea of a private language, which brought thought out of its grotto in the head into the public square where one could look at it, and (...) the 'complex of natural and cultural circumstances which are presupposed in (...) any particular understanding of the world,' seem almost custom designed to enable the sort of anthropological study I, and others of my ilk, do" (Geertz, 2000, p. xii).

13. Similar criticisms can be found in Minogue (1988) or Massingham (1981), who maintains ironically that, as reviewer, Skinner should have considered his book as another example of the old historiography (p. 128). It could apply for him the same regretful remark Foucault made for himself: "perhaps I am an historian of ideas, afterall" (Azouvi, 1992).

14. At my university, History appears in the teacher training curriculum, though still through a subject devoted mainly to study the proposals of the Classics of the Escuela Nueva.

\section{References}

Azouvi, F. (1992). Pour une histoire philosophique des idees. Le Debat, 72, 17-82. http:// dx.doi.org/10.3917/deba.072.0016

Bachman-Medick, D. (2007). Cultural Turns. Hamburg, Germany: Rowohl.

Bleicken, J. (1972). Freiheit. In O. Brunner, W. Conze, \& R. Koselleck (Eds.), Geschichtliche Grundbegriffe: Historisches Lexikon zurpolitisch-sozialen Sprache in Deutschland. Stuttgart, Germanuy: E. Klett. 
Brehony, K. (1997). An 'undeniable' and 'disastrous' influence? Dewey and English education (1985-1939). Oxford Review of Education, 23(4), 427-445. http://dx.doi. org/10.1080/0305498970230401

Bruno-Jofré, R., \& Igelmo Zaldívar, J. (2014, forthcoming). The Center for Intercultural Formation, Cuernavaca, Mexico, its Reports (1962-1967) and Illich's critical understanding of mission in Latin America. Hispania Sacra, extra issue no. 2.

Burke, P. (1997). The history of political and social concepts: A critical introduction. History of European Ideas, 23(1), 55-58.

Bruno-Jofré, R., \& Martínez Valle, C. (2012). Ruralizing Dewey: The American friend, internal colonization, and Escuela de la Acción in post-revolutionary Mexico (19211940). In R. Bruno-Jofré \& J. Schriewer (Eds.), The global reception of John Dewey's thought: Multiple refractions through time and space. London, England: Routledge.

Bruno-Jofré, R., \& Schriewer, J. (Eds.). (2009). Leyendo a John Dewey: Procesos de recepción y adopción en diferentes espacios socio-históricos. Encounters on Education, 10, 3-22.

Bruno-Jofré, R., \& Schriewer, J. (Eds.). (2012). The global reception of John Dewey's thought: Multiple refractions through time and space. London, England: Routledge.

Calvin, J. (1964). Excuse de Iehan Calvin a Messieurs les Nicodemites. In G. Baum, E. Cunitz, \& E. Reuss (Eds.), Ioannis Calvini opera quae supersunt omnia (Vol. 6, pp. 591-614). Frankfurt, Germany: Minerva.

Chartier, A-M. (2007). L'école et la lecture obligatoire. Paris, France: Retz.

Clarke, M. (2013). The mythologies of contextualism. Political Studies, 61, 767-783. http:// dx.doi.org/10.1111/j.1467-9248.2012.01000.x

Gadamer, H. G. (1993). Truth and method. New York, NY: Continuum.

Geertz, C. (2000). Preface. In C. Geertz, Available light: Anthropological reflections on philosophical topics (pp. x-xiv). Princeton, NJ: Princeton University Press.

Geertz, C. (1973). Thick description: Toward an interpretive theory of culture. In C. Geertz, The interpretation of cultures. New York, NY: Basic Books.

Hampsher-Monk, I. (1998). Speech acts, languages or conceptual history? In I HampsherMonk, K. Tilmans, \& F. Van Vree (Eds.), History of concepts: Comparative perspectives. Amsterdam, Netherlands: Amsterdam University Press.

Hunt, L. (2008). Inventing buman rights. New York, NY: Norton.

Howlett, J., \& Mac Donald, P. J. (2011). Quentin Skinner, intentionality and the history of education. Paedagogica Historica, 47(3), 415-433. http://dx.doi.org/10.1080/00309230.2 010.530272

Jay, M. (2013). Intention and irony. History and Theory, 52(1), 32-48. http://dx.doi. org/10.1111/hith.10652

Jones, R. A. (1981). On Quentin Skinner. American Journal of Sociology, 87(2), 453-467. http://dx.doi.org/10.1086/227472

Koselleck, R. (1972a). Einleitung. In O. Brunner, W. Conze, \& R. Koselleck, Geschichtliche Grundbegriffe: Historisches Lexikon zurpolitisch-sozialen Sprache in Deutschland (Vol. 1, pp. XIII-XXVII). Stuttgart, Germany: E. Klett.

Koselleck, R. (1972b). Begriffsgeschichte und Sozialgeschichte. Kölner Zeitschrift für Soziologie und Sozialpsychologie, 16, 116-131.

Koselleck, R., \& Dipper, C. (1998). Begriffsgeschichte, Sozialgeschichte, begriffene 
Geschichte. Neue Politische Literatur, 43, 187-205.

Kössler, T. (2009). Towards a new understanding of the child: Catholic mobilisation and modern pedagogy in Spain, 1900-1936. Contemporary European History, 18(1), 1-24. http:// dx.doi.org/10.1017/S0960777308004803

Keane, J. (1988). More theses on the philosophy of history. In J. Tully (Ed.). Meaning and context: Quentin Skinner and his critics (pp. 204-217). Princeton, NJ: Princeton University Press. http://johnkeane.net/wp-content/uploads/2011/01/jk_theses_philosophy.pdf

Lamb, R. (2009). Quentin Skinner's revised historical contextualism: A critique. History of the Human Sciences, 22(3), 51-73. http://dx.doi.org/10.1177/0952695109104423

Lane, M. (2012). Doing our own thinking for ourselves: On Quentin Skinner's genealogical turn. Journal of the History of Ideas, 73(1), 71-82. http://dx.doi.org/10.1353/ jhi.2012.0002

Lepenies, W. (1981). Anthropologische Tendenzen in der Wissenschaftssoziologie. In B. Schaller et al. (Eds.), Schau unter jeden Stein. Merkwürdiges aus Kultur und Gesellschaft (pp. 179-197). Frankfurt, Germany: Strömfeld.

Massingham, K. R. (1981). Skinner is as Skinner does. Politics, 16, 124-129.

McMahon, D. (2014). The return of the history of ideas. In D. McMahon \& S. Moyn (Eds.), Rethinking modern European intellectual history (pp. 13-31). Oxford, England: Oxford University Press. http://dx.doi.org/10.1093/acprof: oso/9780199769230.003.0001

Minogue, K. (1988). Method in intellectual history. In J. Tully, Meaning and context: Quentin Skinner and his critics (p. 176-193). Princeton, NJ: Princeton University Press.

Olsen, N. (2012). History in the plural: An introduction to the work of Reinhart Koselleck. Frankfurt, Germany: Berghan.

Palonen, K. (2003). Quentin Skinner: History, politics, rhetoric. Cambridge, England: Polity Press. Palonen, K. (2004). Die Entzauberung der Begriffe: Das Umscbreiben der politischen Begriffe bei Quentin Skinner und Reinhart Koselleck. Münster, Germany: LIT Verlag.

Perrot, J. C. (1992). Une histoire intellectuelle de l'économie politique. Paris, France: EHESS.

Popkewitz, T. (2008). Inventing the modern self and John Dewey. London, England: Palgrave Macmillan.

Pozo Andrés, M. (2007). Desde L'Ermitage a la Escuela Rural Española. Revista de Educación, 1, 143-166.

Revel, J. (2010). The uses of comparison. In L Hunt, M. Jacob, \& W. Mijnhardt (Eds.), Bernard Picard and the first global vision of religion. Los Angeles, CA: Getty Publications.

Röhrs, H., \& Lehnhart, V. (1994). Die Reformpädagogik auf den Kontinenten. Frankfurt, Germany: Lang.

Richter, M. (1990). Reconstructing the history of political Languages: Pocock, Skinner, and the Geschichtliche Grundbegriffe. History and Theory, 29, 39-70.

Richter, M. (1995). The history of political and social concepts. Oxford, England: Oxford University Press. http://dx.doi.org/10.2307/2505203

Schmidt, M. (2012). Marcel Proust (1871-1922): A modernist novel of time. In M. Bell (Ed.), The Cambridge companion to European novelists (pp. 327-342). Cambridge, England: Cambridge University Press. http://dx.doi.org/10.1017/CCOL9780521515047.021

Skinner, Q. (1969). Meaning and understanding in the history of ideas. History and Theory, 8, 
3-53. http://dx.doi.org/10.2307/2504188

Skinner, Q. (1978). The foundations of modern political thought. Cambridge, England: Cambridge University Press. http://dx.doi.org/10.1017/CBO9780511817878

Skinner, Q. (1988). A reply to my critics. In J. Tully (Ed.), Meaning and context: Quentin Skinner and his critics (pp. 231-289). Cambridge, England: Polity.

Skinner, Q. (2002). Vision of politics: Regarding method. Cambridge, England: Cambridge University Press. http://dx.doi.org/10.1017/CBO9780511613777

Skinner, Q. (2009). A genealogy of the modern state. Proceedings of the British Academy, 162, 325-370.

Skinner, Q., Koikkalainen, P., \& Syrjämäki, S. (2002). On encountering the past - Interview with Quentin Skinner. Finnish Yearbook of Political Thought, 6, 32-63.

Schriewer, J. (1999). Vergleich und Erklärung zwischen Kausalität und Komparatistik. In H. Kaelble \& J. Schriewer (Eds.), Diskurse und Entwicklungspfade (pp. 53-104). Frankfurt, Germany: Campus.

Schriewer, J., \& Martínez Valle, C. (2003). World-level ideology or nation-specific system-reflection? Reference horizons in educational discourse. Lisbon, Portugal: Educa.

Schriewer, J., \& Martínez Valle, C. (2004). Construction of internationality in education. In G. Steiner-Khamsi (Ed.), The global politics of educational borrowing and lending (pp. 29-53). New York, NY: Teachers College Press.

Tröhler, D. (2013). Los lenguajes de la educación. Barcelona, Spain: Octaedro.

Tully, J. (1988). The pen is a mighty sword: Quentin Skinner's analysis of politics. In J. Tully (Ed.), Meaning and context: Quentin Skinner and his critics (pp. 7-25). Cambridge, England: Polity.

Tuck, R. (1993). The contribution to history. In R. Goodin \& P. Pettit (Eds.), A companion to contemporary political philosophy (pp. 72-89). Oxford, England: Blackwell.

Viswanathan, G. (1989). Masks of conquest: Literary study and British rule. New York, NY:

Columbia University Press. 